\title{
Autism-facial port-wine stain syndrome
}

INSERM

\section{Source}

INSERM. (1999). Orphanet: an online rare disease and orphan drug data base. Autismfacial port-wine stain syndrome. ORPHA:137911

This syndrome is characterised by the presence of a unilateral angioma on the face and autistic developmental problems characterised by language delay and atypical social interactions. 